\title{
Formulasi Waktu Salat Perspektif Fikih dan Sains
}

\author{
Rizal Mubit \\ Nusantara Centre \\ (Email: rijal_mufi@yahoo.co.id)
}

\begin{abstract}
Abstrak
Salat merupakan salah satu dari rukun Islam yang istimewa dimana pelaksanannya sudah ditentukan sedemikian rupa. Perlu konsep kejelasan waktu yang tepat untuk dijadikan patokan waktu mulai pada jam dan menit ke ke berapa salat harus dilaksanakan. Ada dua cara yang bisa dilakukan untuk mengetahuinya. Secara fikih dan sains. Secara fikih, waktu sholat bisa diketahui dengan fenomena gerakan matahari. Sedangkan dari sudut pandang sains, waktu salat bisa diketahui dengan menggunakan sains yang dalam Islam dikenal dengan ilmu hisab. Kedua metode penentuan waktu salat tersebut pada dasarnya saling mendukung satu sama lain. Kedua metode tersebut, baik sains maupun fikih perlu untuk diterapkan dan dikembangkan. Sejauh ini tidak ada permasalahan penentuan waktu salat baik dengan fikih atau sains. Berbeda dengan penentuan awal bulan kamariyah yang sampai saat ini masih menjadi perbedaan.
\end{abstract}

Kata Kunci: Waktu Salat, Fikih, Sains

\section{A. Pendahuluan}

Salat merupakan ibadah fundamental dan signifikan dalam Islam. Adapun mengenai penetapan waktu salat, ditemukan bahwa teksteks yang dijadikan landasan bersifat interpretatif. Sebagai implikasinya muncul perbedaan dalam menetapkan awal waktu salat. Kelompok pertama berpandangan bahwa awal waktu salat ada tiga. Sementara itu, kelompok kedua menyebutkan bahwa awal waktu salat ada lima. ${ }^{1}$ Pendapat pertama banyak diterima oleh golongan Syiah. Sedangkan mayoritas muslim di Indonesia, lebih memegangi pendapat yang kedua.

Secara syar'i, dalam menunaikan kelima waktu salat tersebut, kaum muslimin terikat pada waktu-waktu yang sudah ditentukan sebagaimana Firman Allah dalam surat An Nisa' (4): 103, Artinya: Maka apabila kamu telah menyelesaikan salat(mu), ingatlah Allah di waktu

\footnotetext{
Menurut Muhammad Jawad Muqniyyah, dalam kitab At-Tafsir al-Kasif, $15: 74$
}

berdiri, di waktu duduk dan di waktu berbaring. Kemudian apabila kamu telah merasa aman, Maka dirikanlah salat itu (sebagaimana biasa). Sesungguhnya salat itu adalah fardhu yang ditentukan waktunya atas orangorang yang beriman. (QS. An Nisa': 103)

Konsekwensi logis dari ayat tersebut adalah salat tidak bisa dilakukan dalam sembarang waktu, melainkan harus mengikuti atau berdasarkan dalil-dalil baik dari AlQur'an maupun Al-Hadis. Dapat dipahami bahwa betapa pentingnya penentuan awal waktu salat. Penentuan awal waktu salat ini dapat diperoleh dengan menggunakan cara melihat langsung pada tanda-tanda alam sebagaimana secara tekstual dalam hadis-hadis Nabi, seperti menggunakan alat bantu rubu',

2 Rubu' berarti seperempat. Dalam istilah astronomi disebut kuadran (quadrant), yaitu suatu alat untuk menghitung fungsi goniometris yang sangat berguna untuk memproyeksikan peredaran benda langit pada lingkaran vertical. Lihat Susiknan Azhari, Ensiklopedi Hisab Rukyat, Yogyakarta: 
tongkat istiwa' atau miqyas yang dalam astronomis lebih dikenal dengan sundial ${ }^{3}$.Selain itu, waktu salat dapat

Pustaka Pelajar, cet. 1, 2005, hlm. 129. Rubu'al-Mujayyab atau Kuadran sinus merupakan alat perangkat hitung astronomis untuk memecahkan permasalahan astronomi bola. Tokoh-tokoh yang berperan dalam pengembangan rubu' ini adalah al-Khwarizmi (770-840) dan Ibn-Sathir (abad 11). Rubu'alMujayyab yang berkembang di Indonesia ialah rubu' hasil pengembangan dari rubu' IbnSathir. (Lihat Hendro Setyanto, Kajian Kitab-Forum Kajian Ilmu Falak "Zenith", Rubu', Bandung: Pundak Scintific, 2001, hlm. 3) dalam kitab-kitab falak klasik biasanya menggunakan metode penentuan awal waktu salat dengan menggunakan rubu'.

${ }^{3}$ Lihat Sundial; History, Theory, \& Practice by Rene R.J.Rohr; translated by Gabriel Godin, Toronto: University of Toronto Press, 1970.Dalam buku ini, ada beberapa istilah yang dapat diartikan sebagai jam matahari atau sundial, yaitu hemisphere dan gnomons. Sundial (jam matahari) adalah seperangkat alat yang digunakan sebagai petunjuk waktu semu lokal (local apparent time) dengan memanfaatkan matahari yang menghasilkan bayang-bayang sebuah gnomon yaitu, batang atau lempengan yang bayangbayangnya digunakan sebagai petunjuk waktu (gnomon merupakan salah satu bentuk dari sundial sederhana, oleh karena itu dianggap sebagai nama lain dari sundial), chapter three, Classical Sundials, hlm. 46. Pada dasarnya, sebuah sundial terdiri dari satu objek yang membentuk satu bayangan dari sebuah permukaan yang bergaris, yang disebut dengan garis jam. Permukaan tersebut dinamakan table jam. (Basically, a sundial consists of a surface on wich lines (the so-called hour-lines) have been traced; the surface is called the table of the dial). Jika kita meruntut sejarah, menurut data literatur papyrus pada tahun 1450 SM, sundial pernah dipakai di Mesir dalam bentuk obelisk yang saat itu digunakan untuk menentukan waktu dan menseting kalender. Groping through history with this Ariadne's thread, we learn from the papyri that by about 1450 BC gnomons in the form of obelisks were used in Egypt for the measurement of time and the setting up of calendar. Sekitar tahun 1000, bangsa Arab telah menjadi ahli waris dari gnamon Yunani sebagaimana ilmu klasik lainnya. 15 buku mereka tentang gnomonic ditulis dari abad 1114. By around the year 1000, the Arabs had become the inheritors of Greek Gnomonics, as diketahui melalui jadwal salat abadi atau jadwal salat sepanjang masa, serta jadwal-jadwal salat dari hasil hisab penentuan awal waktu salat yang ada dan berkembang dalam masyarakat sekarang ini. Hisab ini menghitung dan memperkirakan kapan matahari akan menempati posisi-posisi seperti tersebut dalam nash-nash waktu salat.

Atas dasar kebutuhan pada masa modern ini, hisab penentuan awal waktu salat melangkah ke arah kemajuan dengan lahirnya softwaresoftware penentuan waktu salat yang memudahkan masyarakat dalam mengetahui awal dan akhir waktu salat. Jadwal salat sekarang ini juga mudah didapatkan dalam kalenderkalender yang beredar dalam masyarakat oleh perhitungan hisab para ahli falak. Hampir di setiap kalender telah dicantumkan jadwal awal waktu salat. Jadwal awal waktu salat yang ada dalam kalenderkalender tersebut dapat disesuaikan dengan daerah masing-masing.

\section{B. Formula Penentuan Awal Waktu Salat}

Perkembangan ilmu astronomi telah membantu umat Islam dalam melakukan perhitungan waktu sehingga salat bisa diketahui tanpa harus melihat fenomena alam. Secara umum proses perhitungan waktu salat, ada beberapa data yang diperlukansebagai berikut:

\section{MeridianPass (MP)}

well as of all the ather ancient sciences. Fifteen of their books on gnomoniccs written during the period from the elevent to the fourteenth century ave survived, Chapter one, History of The Sundial hlm. 5. Kemungkinan pada masa ni, kemudian umat Islam memanfaatkan sundial untuk menentukan awal waktu salat. Dalam bahasa Arab disebut juga as-Sa'ah asy-Syamsiah atau mizwala. Lihat juga pada Susikanan Azhari, Ensiklopedi Hisab Rukyat, (Yogyakarta: Pustaka Pelajar, 2005), cet. 1,hlm. 144. 
Saat matahari berkulminasi dinyatakan dengan istilah Meridian Pass (MP). Data saat kulminasi matahari dapat diperoleh dengan cara mengurangi Waktu Hakiki (waktu matahari) dengan Perata Waktu (Equation of Time yang disimbolkan dengan e). Dengan demikian MP dapat dirumuskan, $\mathrm{MP}=$ Kulminasi equation of time atau lebih sederhananya, MP $=12-$ e. $^{4}$

Waktu hakiki atau waktu matahari selalui menunjukkan pukul 12.00 pada saat matahari berkulminasi. Padahal perjalanan harian matahari itu sebenarnya tidak benar-benar rata. Adakalanya lambat dan adakalanya cepat. Satu putaran kadang ditempuh dalam 24 jam tepat, kadang kurang, dan kadang lebih. Akibatnya Waktu Hakiki itu boleh jadi berselisih beberapa menit dengan Waktu Pertengahan, atau jam arloji, yang jalannya benar-benar rata. Selisih antara Waktu Hakiki dengan Waktu Pertengahan itu disebut Perata Waktu. Jika perjalanan matahari itu lambat maka nilai perata waktu negatif (-), dan jika perjalanan matahari cepat maka harga perata waktunya positif (+).

\section{Sudut Waktu Matahari Awal Waktu} Salat ( t )

Dinamakan sudut waktu, karena bagi semua benda langit yang terletak pada lingkaran waktu yang sama akan berkulminasi pada waktu yang sama pula (atau jarak waktu yang memisahkan benda langit tersebut dari kedudukannya sewaktu berkulminasi sama). Besarnya sudut waktu itu menunjukkan berapakah jumlah waktu yang memisahkan benda langit tersebut dari kedudukannya sewaktu berkulminasi. Jika benda langit sedang berkulminasi, maka harga t-nya $=0^{\circ}$.

${ }^{4}$ Lihat Muhyiddin Khazin, Muhyiddin Khazin, Ilmu Falak; dalam Teori dan Praktik, (Yogyakarta: Buana pustaka), hlm. 56
Besar $\mathrm{t}$ diukur dengan derajat sudut dari $0^{\circ}-180^{\circ}$ dan selalu berubah $\pm 15^{\circ}$ \% jam, karena gerak harian benda-benda langit. $^{5}$

Sudut waktu adalah sudut yang dibentuk oleh setiap lingkaran waktu dengan lingkaran meridian. Sudut waktu matahari adalah jarak matahari dari titik kulminasi diukur sepanjang lintasan harian. Sudut waktu disebut juga Hour Angle atau dalam bahasa Arab disebut fadl al-daair. Sudut waktu ada dua macam :

a. Sudut waktu Positif (+) yaitu sudut waktu untuk benda langit yang sudah melewati titik kulminasinya, dari $0^{\circ}$ sampai $180^{\circ}$.

b. Sudut waktu Negatif (-) yaitu sudut waktu untuk benda langit yang belum melewati titik kulminasinya, dari $0^{\circ}$ sampai $-180^{\circ}$.

Rumus Sudut Waktu Matahari Awal Waktu Salat ( t ) : ${ }^{6}$

$\cos t-\sin h-\cos \Phi+\cos -\tan \Phi x \tan d$
3. Koreksi Waktu Daerah (KWD) Untuk memindahkan waktu istiwa' yang dihasilkan oleh perhitungan awal waktu salat yang menggunakan data-data GMT, maka harus dilakukan koreksi untuk mengetahui waktu setempat. Rumus koreksi waktu daerah :

$$
\left(\lambda_{\mathrm{dh}}-\lambda_{\mathrm{tp}}\right) \div 15
$$

Keterangan: 
$\lambda_{\mathrm{dh}}:$ Bujur Daerah

$\lambda_{\text {tp }}$ : Bujur Tempat

Sebagai upaya dalam

mengatasi kesulitan karena adanya perbedaan waktu pada setiap wilayah di dunia, maka dibentuk waktu daerah yang disesuaikan menurut bujur daerah tersebut yang berpedoman dengan meridian yang melintasi kira-kira pada pertengahan daerah bersangkutan. Bujur daerah Indonesia sendiri sejak tanggal 1 Januari 1964 terbagi menjadi 3 bagian, yaitu:

a. Waktu Indonesia Barat: $105^{\circ}$ dengan zona waktu GMT $+7^{\mathrm{j}}$

b. Waktu Indonesia Tengah: $120^{\circ}$ dengan zona waktu GMT $+8^{\mathrm{j}}$

c. Waktu Indonesia Timur: $135^{\circ}$ dengan zona waktu GMT $+9^{j}$

Sebagai batas diantara bujur daerah-daerah waktu tersebut diambil dari garis bujur yang terdapat pada pertengahan meridian-merdian waktu daerah yang berbatasan yang juga ditentukan oleh perbatasan pemerintahan dari daerah tersebut. ${ }^{7}$

\section{Ihthiyat \\ Ialah suatu langkah pengamanan dengan cara menambahkan atau mengurangkan waktu agar jadwal waktu salat tidak mendahului awal waktu atau akhir waktu. ${ }^{8}$ Ihtiyat dari segi kegunaannya dibagi menjadi tiga, yaitu: ${ }^{9}$}

a. Ihtiyat guna luasnya daerah, berarti memindahkan meridian yang kita pedomani ke batas sebelah barat ataupun sebelah timur dari daerah hisab. Hal ini digunakan untuk mempertimbangkan perbedaan waktu salat antara daerah

\footnotetext{
${ }^{7}$ Abd. Rachim..., hlm. 55-57

8 Depag RI, Pedoman Penentuan

Jadwal Waktu Salat Sepanjang Massa,(Jakarta: Depag, 1994), hlm. 38

${ }^{9}$ Abdur Rachim..., hlm. 53
}

bagian timur dan barat yang biasanya terdapat selisih dalam berbuka puasa. Ihtiyat ini juga digunakan untuk menentukan lintang dan bujur suatu tempat yang biasanya diukur dari suatu titik (markaz) di pusat kota yang mewakili daerah tersebut.

b. Ihtiyat guna koreksi sesaat dalam hasil hisab, digunakan untuk mengoreksi atas datadata yang kita ambil sebagai ketelitian.

c. Ihtiyat guna keyakinan, digunakan untuk menandai waktu imsak (puasa) yang dimajukan beberapa menit dari awal Subuh atau juga beberapa menit yang diundurkan dari waktu Dzuhur untuk menghilangkan keragu-raguan atas larangan mengerjakan salat pada saat matahari berkulminasi.

Direktorat Pembinaan Badan Peradilan Agama Islam sebagaimana Saadoeddin Djambek, mempergunakan ihtiyat 2 menit, yang dianggap cukup memberikan pengaman terhadap koreksi data ratarata dan mempunyai jangkauan 27,5 $55 \mathrm{~km}$ ke arah barat atau timur. ${ }^{10}$

Dari keterangan di atas, maka dapat diformulasikan data dan rumus yang digunakan dalam penentuan waktu salat adalah sebagai berikut:

\section{Meridian Pass} $\mathrm{MP}=12-\mathrm{e}$

2. Rumus sudut waktu matahari $\cos t=\sin h \div \cos \Phi \div \cos \delta-\tan \Phi x \tan \delta$

3. Rumus tinggi matahari $\left(\mathrm{h}_{\mathrm{o}}\right)$

- Ashar : Cotan $\mathrm{h}_{\mathrm{o}}=\tan \mathrm{zm}+1$ atau $\mathrm{zm}=[\varphi-\delta]$

- Maghrib: - $(\mathrm{ku}+\mathrm{ref}+\mathrm{sd})-1^{\mathrm{o}}$

- Isya': $17+-(\mathrm{ku}+\mathrm{ref}+\mathrm{sd})-18^{\circ}$

- Subuh : - $19+-(\mathrm{ku}+\mathrm{ref}+\mathrm{sd})-20^{\circ}$

- Terbit : $(\mathrm{ku}+\mathrm{ref}+\mathrm{sd}) 1^{\mathrm{o}}$

${ }^{10}$ Depag..., hlm. 39 
4. Rumus koreksi waktu daerah : $\mathrm{Kwd}=\left(\lambda_{\text {dh }}-\lambda_{\text {tp }}\right) \div 15$

Sehingga rumus awal waktu salat:

1. Dzuhur $=\mathrm{MP}+\mathrm{Kwd}+\mathrm{i}$

2. Ashar $=\mathrm{MP}+\mathrm{t} \div 15+\mathrm{Kwd}+\mathrm{i}$

3. Maghrib $=\mathrm{MP}+\mathrm{t} \div 15+\mathrm{Kwd}+\mathrm{j}$

4. Isya' $=\mathrm{MP}+\mathrm{t}+15+\mathrm{Kwd}+\mathrm{j}$

Subuh $=$ MP $-\mathrm{t} \div 15+\mathrm{K} w d+\mathrm{i}$

\section{Faktor yang Mempengaruhi Penentuan Awal Waktu Salat}

1. Faktor yang Mempengaruhi Penentuan Awal Waktu Salat

\section{a) Deklinasi \\ Declination \\ /Apparent}

Jarak titik pusat benda langit sepanjang lingkaran deklinasi sampai ke equator dinamakan deklinasi atau apparent declination. ${ }^{11}$ Pada kitab falak klasik biasanya menggunakan dengn bahasa Arab ميل الثمس, untuk deklinasi matahari, dan ميل القمر. untuk deklinasi bulan.

Deklinasi matahari berubah sewaktu-waktu selama satu tahun, dan pada tanggal-tanggal tertentu, yaitu 21 Maret - 23 September deklinasi matahari positif karena dibagian utara. Sedangkan pada tanggal 23 September - 21 Maret deklinasi matahari berada di selatan dan disebut negative. Pada tanggal tersebut matahari bernilai $0^{\circ}$. Setelah tanggal 21 Maret matahari mulai bergerak ke Utara menjauhi equator hingga tanggal 21 Juni mencapai nilai $23^{\circ} 26^{\prime}$ Utara atau dalam bahasa Arab disebut ميل لأعظم.

\footnotetext{
${ }^{11}$ Muhyiddin Khazin..., hlm. 65

${ }^{12}$ Dalam kitab Khulashatul Al Wafiyah disebutkan bahwa deklinasi terjauh (mailul 'adzom) khulashoh $23^{\circ}$ 27', Lihat Zubair Umar Al Jailani, Khulashatul Al Wafiyah, (Kudus: Penerbit Menara Kudus, tt). hlm. 81. Begitupun yang terdapat dalam Ephimeris deklinasi terjauh $23^{\circ} 27^{\prime}$, sedangkan dalam Tibyanul Miqat $23^{\circ}$ 52'. Lihat juga pada Maksum bin Ali, Tibyan Al Miqat fi Ma'rifat Al Auqat wa Al Qiblah, (Kediri: Madrasah Salafiyah Al Falaki, tt,) hlm. 12
}

Setelah itu, matahari mulai berbalik arah mendekati equator hingga tanggal 23 September. Kemudian bergerak terus ke selatan menjauhi matahari hingga mencapai bilangan $23^{\circ} 26^{\prime}$ yaitu tanggal 22 Desember. Lalu berbalik lagi ke arah utara mendekati equator hingga tanggal 21 Maret. $^{13}$

b) Equation of Time.

Perlu Anda ketahui bahwa lintasan bumi ketika mengelilingi matahari berbentuk elips (agak lonjong seperti telur). Oleh karenanya jarak bumi dan matahari tidak tetap setiap saat, kadang-kadang dekat dan kadang-kadang jauh. Jarak terdekat bumi dengan matahari dinamakan Perigee yang dalam bahasa Arabnya dinamakan حضيض dan jarak terjauhnya dinamakan Apogee yang dalam bahasa Arabnya dinamakan . Dekat tidaknya bumi dengan matahari ini berdampak pada kecepatan gerak bumi, dimana ketika jaraknya dekat dengan matahari, pergerakan bumi pada lingkaran ekliptika berlangsung lebih cepat daripada ketika jaraknya jauh. Akibatnya, saat kulminasi matahari setiap hari senantiasa berubah, kadang persis jam 12:00, kadang kurang dan kadang lebih dari jam 12:00. Selisih antara kulminasi matahari hakiki dengan waktu kulminasi matahari rata-rata (jam 12:00) dinamakan Equation Of Time yang dalam bahasa Indonesia dinamakan Perata Waktu, dalam bahasa Arab mempunyai beberapa nama antara lain : , تعديل الوقت , dan

2. Faktor yang Mempengaruhi Penentuan Awal Waktu Salat Daerah satu dengan Daerah lain

a) Koordinat Lintang Tempat ( ). Lintang adalah jarak dari suatu tempat ke khatulistiwa diukur dengan

${ }^{13}$ Abd Rachim..., hlm. 8 
melalui meridian bumi. Dalam bahasa Arab dinamakan dan biasanya ditandai dengan huruf Yunani

(phi, cara baca : fi). Daerah yang terletak di sebelah utara garis khatulistiwa (ekuator) memiliki lintang positif, dan untuk daerah yang terletak disebelah selatan garis khatulistiwa memiliki lintang negatif. ${ }^{14}$

Perbedaan lintang tidak sama besar pengaruhnya terhadap waktu salat sepanjang tahun. ${ }^{15}$ Hal ini berkaitan dengan nilai deklinasi matahari yang berbeda-beda dalam setiap waktu.

b) Koordinat Bujur Tempat $(\lambda)$.

Bujur astronomi suatu tempat adalah sudut antara bidang di meridian tempat dan bidang meridian dari Greenwich. ${ }^{16}$ Dalam bahasa Arab bujur tempat itu dinamakan yang biasanya ditandai dengan lambang astronomi dengan huruf Yunani $\lambda$ (cara baca : lamda).

Kesepakatan internasional menetapkan permulaan perhitungan garis bujur bumi (bujur $0^{\circ}$ ), di mulai pada garis bujur yang melintasi kota Greenwich di Inggris. Daerah yang terletak di sebelah timur Greenwich sampai $180^{\circ}$ memiliki bujur positif dan untuk daerah yang terletak di sebelah barat Greenwich sampai $180^{\circ}$ memiliki bujur negatif. Tanda nilai bujur ini berhubungan dengan waktu, artinya untuk mendapatkan standar waktu

14 Baca K.J. Vilianueva,Pengantar ke dalam Astronomi Geodesi, (Bandung: Departemen Geodesi Fakultas Teknik Sipil dan Perencanaan Institut Teknologi Bandung, 1978), hlm. 4

${ }^{15}$ MuntohaAnalisis Terhadap Toleransi Pengaruh Perbedaan Lintang dan Bujur dalam Kesamaan Penentuan Awal Waktu Shalat, Skripsi Fakultas Syariah IAIN Walisongo Semarang, 2004, hlm. 52. Hal ini yang membuat beberapa ahli falak meniadakan konversi waktu daerah untuk jadwal waktu salat, salah satunya Tim Lajnah Falakiyah Lirboyo.

$$
{ }^{16} \text { Lihat Muntoha, hlm. } 114 .
$$

internasional GMT, wilayah barat (bujur barat) harus dikurangi angka tertentu. Sebaliknya, bujur timur harus ditambah angka tertentu. Garis bujur timur $180^{\circ}$ dan garis bujur barat $180^{\circ}$ bertemu dan berhimpit dilautan Pasifik dan dijadikan garis batas tanggal dalam penanggalan Masehi.

Sebagaimana yang dikutip dari skripsi Muntoha yang berjudul Analisis Terhadap Toleransi Pengaruh Perbedaan Lintang dan Bujur dalam Kesamaan Penentuan Awal Waktu Salat, dijelaskan bahwa perbedaan bujur cukup besar pengaruhnya terhadap masuknya waktu salat. ${ }^{17}$

Perbedaan $1^{\circ}$ bujur berarti perbedaan 4 menit waktu, perbedaan bujur sebesar $0,1^{\circ}$ atau jarak tepat ke timur atau tepat ke barat sejauh $11 \mathrm{~km}$ berarti perbedaan waktu sebanyak 0,4 menit atau 24 detik. Jarak $271 / 2 \mathrm{~km}$ tepat ke barat atau ke timur berarti perbedaan waktu sebanyak satu menit.

c) Zona Waktu Tempat (z).

Pada dasarnya bumi dibagi dalam 24 wilayah waktu (zona waktu) yang dibatasi oleh meridian-meridian dengan selisih bujur $15^{\circ}$ (1 jam). Dalam tiap wilayah ini berlaku satu macam waktu wilayah dengan meridian tengahnya sebagai referensi. Wilayah $0^{\circ}$ meridian referensinya adalah meridian Greenwich. Daerahyang terletak di sebelah timur Greenwich memiliki $\mathrm{z}$ positif, sedangkan di sebelah barat Greenwich memiliki z negatif. Untuk wilayah ke12 dibagi dua oleh "dateline" dan untuk bagian barat diambil $\mathrm{z}=-12$ sedangkan untuk bagian yang timur diambil $\mathrm{z}=+12$. Bila seseorang melewati "date line" maka ia harus menyesuaikan hari kalendernya dengan menambah atau mengurangi dengan satuan hari $\left(24^{j}\right)$. Untuk keseragaman di suatu negara maka

\footnotetext{
${ }^{17}$ Muntoha..., hlm. 51
} 
wilayah waktu itu disesuaikan dengan batas-batas negara. Misalnya zona waktu Jakarta adalah UT +7 (Universal Time) atau seringkali disebut GMT +7 (Greenwich Mean Solar Time), maka $\mathrm{z}=7$. Misalnya, Los Angeles memiliki $\mathrm{z}=-8 .^{18}$

Untuk Indonesia sendiri dibagi dalam 3 zona waktu, yaitu Waktu Indonesia Barat (+7), Waktu Indonesia Tengah (+8), dan Waktu Indonesia Timur (+9). Tanda waktu dari masingmasing daerah di wilayah Indonesia biasanya dapat dikoreksi dengan adanya tanda waktu yang dipersiapkan oleh Badan Meteorologi Klimatologi dan Geofisika yang biasanya disiarkan oleh Radio Republik Indonesia pada jam-jam tertentu.

d) Ketinggian Tempat dari Permukaan Laut (h).

Ketinggian lokasi dari permukaan laut (h) menentukan waktu kapan terbit dan terbenamnya matahari. Tempat yang berada tinggi di atas permukaan laut akan lebih awal menyaksikan matahari terbit serta lebih akhir melihat matahari terbenam, dibandingkan dengan tempat yang lebih rendah. Satuan h adalah meter atau feet (kaki). ${ }^{19}$

\section{Formulasi Waktu Salat Perspektif Syar'i dan Sains}

Pada dasarnya, banyak hadis yang memperjelas waktu salat yang telah disebutkan dalam Al-qur'an, namun penulis di sini hanya memngambil dua hadis yang menurut penulis jelas penggambarannya mengenai waktu salat. Sebagaimana hadis riwayat Jabir bin Abdulla r.a. telah memberi gambaran kelima waktu salat secara lebih jelas dengan posisiposisi matahari yang menjadi patokan waktu. Matahari tidak hanya berfungsi

\footnotetext{
${ }^{18}$ Lihat Muntoha, hlm. 70-71.

19 Satu meter sama dengan 3,048 feet
}

menghangatkan biosfer bumi dengan cahayanya, namun dengan bayangbayang benda atau tongkat istiwa matahari dapat berperan untuk mengatur ritme kewajiban dzikir manusia kepada Tuhannya. Dari kelima waktu salat menggunakan matahari sebagai patokan dalam perhitungannya. Dalam penentuan waktu salat, posisi matahari dalam koordinat horizon sangat diperlukan, terutama ketinggian atau jarak zenith.

\section{Salat Dzuhur}

$$
\text { فصله الظهر حين }
$$

(kemudian Nabi salat Dzuhur ketika matahari tergelincir)

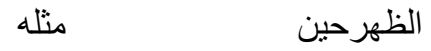

(kemudian Nabi salat Dzuhur dikala bayang-bayang suatu benda sama dengan aslinya).

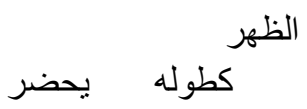

(waktu Dzuhur apabila tergelincir matahari sampai bayang-bayang seseorang sama dengan tingginya yaitu selama belum datang waktu Ashar)

Para ahli fiqh memulai dengan salat Dzuhur, karena ia merupakan salat pertama yang diperintahkan (difardhukan). Kemudian setelah itu difardhukansalat Ashar, kemudian Maghrib, lalu Isya', kemudian salat Subuh secara tartib. Kelima salat tersebut diwajibkannya di Makkah pada malam isra' setelah 9 tahun dari di utusnya Rasulullah. Hal demikian berdasarkan firman Allah surat AlIsra' ayat $78 .^{20}$

${ }^{20}$ Muhammad Jawa Mughniyyah, Fiqih Lima Madzhab, Diterjemahkan oleh Masykur dkk dari Al-Fiqh 'ala Al-Madzahib AlKhamsah, (Jakarta: Lentera, 2007), cet VI hlm 74. Peristiwa isra' mi'raj disebutkan dalam surat Al-Isra' ayat 1 dan terdapat penjelasan mengenai bertemunya Rasulullah dengan Jibril dalam bentuk aslinya dan kebesaran-kebesaran 
Pada hadis pertama yang diriwayatkan oleh Jabir, disebutkan bahwa Jibril datang menyuruh Nabi salat dzuhur pada hari pertama setelah tergelincir matahari, dan datang lagi diwaktu Ashar saat bayangan benda sama dengan benda tersebut. Pada hari kedua, Jibril datang menyuruh salat Dzuhur pada waktu bayangan benda sama dengan benda itu sendiri, tepat

Allah yang disebutkan dalam surat An-Najm ayat 5-18. Sedangkan turunnya perintah salat 5 waktu didapatkan dari Hadis riwayat Bukhari yang diriwayatkan dari Anas bin Malik. Dari hadis tersebut dikabarkan bahwa Rssul saat mi'raj bertemu dengan dengan para nabi terdahulu dan turun perintah salat 50 waktu dalam sehari-semalam. Dalam perjalanan kembali, Rasul bertemu dengan Nabi Musa yang selanjutnya memberi nasehat untuk meminta keringanan atas perintah salat yang diterima Rasul, karena umat Rasul dinilai tidak akan sanggup mengerjakannya sebagaimana Nabi Musa mencobakannya pada umat dari Bani Israil terdahulu. Oleh karena itu diceritakan bahwa Rasul meminta keringanan beberapa kali kepada Allah sehingga perintah salat menjadi 5 waktu dalam sehari-semalam. Sebenarnya Nabi Musa masih menyarankan agar Rasul meminta keringan lagi, namun Rasul menolak dan berkata,"Aku telah meminta terlalu banyak dari Tuhanku dan itu membuatku malu. Tapi aku rasa sekarang aku gembira dan berserah diri kepada perintah Allah." Dan ketika Rasul pergi, beliau mendengar suara berkata "Aku telah memberikan perintahKu dan telah mengurangi beban para hambaKu". Selengkapnya lihat pada Hadis riwayat Bukhari no. 349 dalam AlJami 'Shahih Al Bukhari, (Beirut: Dar Al Fikr, tt), hlm. 382. Hadis ini dinalai shahih dengan sanad Yahya bin Abu Bukair, Lais bin Su'dan, Yunus, dan Muslim bin Abdullah bin Syihab yang dianggap muttasil dan dikenal sebagai perawi-perawi yang dapat dipercaya. Lihat pada Syekh Syihabuddin Abi al Fadhal Ahmad bin Ali bin Hajar Al Asqalani, Tahdzib al Tahdzib, (Beirut: Dar Al Kitab Al Islami, $852 \mathrm{H}$ ), hlm. 178-445. Dan juga lihat pada Syekh Islam Abi Muhammad Abd Rahman bin Abi Hatim Muhammad, Al Jarah wa Ta'dil, (Beirut: Dar Al Kutub, 1373 H), hlm. 247, serta lihat pula Imam Hafiz Syamsuddin Muhammad bin Ahmad adz Dzahbi, Mizan Al I'tidal, (Beirut: Dar Al Kutub Al Islamiyah, tt), hlm. 515. pada waktu melakukan salat Ashar pada hari pertama. ${ }^{21}$

Sedangkan pada hadis kedua dijelaskan bahwa waktu Dzuhur ialah bila matahari sudah tergelincir; atau oleh ulama lain diartikan condong ke Barat; hingga bayang-bayang seseorang sama dengan tingginya atau saat bayang-bayang suatu benda sama panjangnya dengan benda tersebut. Kata "ka-na" diathafkan terhadap kata "za-lat", yang maksudnya waktu Dzuhur itu tetap berlangsung hingga terjadi bayangan orang sama dengan tinggi badannya, selama belum masuk waktu Ashar. Inilah batasan bagi permulaan dan akhir waktu Dzuhur. ${ }^{22}$

Dalam hal ini, para ulama' sependapat bahwa penentuan awal waktu Dzuhur, adalah pada saat tergelincirnya matahari. Sementara dalam menentukan akhir waktu Dzuhur, ada beberapa pendapat yaitu sampai panjang bayang-bayang sebuah benda sama dengan panjang bendanya (menurut Imam Malik, Syafi'I, Abu Tsaur dan Daud). Sedangkan pendapat Imam Abu Hanifah ketika bayangbayang benda sama dengan dua kali bendanya. $^{23}$

Secara

tergelincirnya matahari diwaktu Dzuhur dapat dikatakan bahwa matahari sedang berkulminasi atas, yaitu ketika matahari meninggalkan meridian. Secara ilmu pasti ialah pada saat titik pusat matahari bergerak dari meridian, atau saat bayang-bayang benda condong ke arah Timur dan sudut yang dihasilkan dengan garis

${ }^{21}$ Abu Bakar Muhammad, Subulus

Salam, (Surabaya: Al-Ikhlas), hlm. 306

${ }^{22}$ Abu Bakar, hlm. 305

${ }^{23}$ Al Faqih Abul Wahid Muhammad Bin Ahmad Bin Muhammad Ibnu Rusyd, Bidayatul Mujatahid Analisa Fiqih Para Mujtahid, di terjemahkan oleh Imam Ghazali dkk, dari Bidayatul Mujtahid Wa Nihayatul Muqtasid, Jakarta : Pustaka Amani, 2007, hlm. 66 
i'tidal (garis timur-barat) bukan lagi $90^{\circ} .^{24}$

Tinggi kulminasi matahari setiap hari berubah, karena adanya deklinasi. Untuk mengetahui besarnya tinggi kulminasi, harus diketahui lebih dahulu $z m$ matahari, yaitu jarak titik pusat matahari saat kulminasi dari zenith yang dapat diperoleh dengan rumus, $z m=[\varphi-\delta]$. Dengan kata lain, jarak zenith titik pusat matahari saat kulminasi besarnya sama dengan harga mutlak lintang tempat dikurangi deklinasi. Oleh karena itu, dalam penentuan awal waktu salat, maka dapat dirumuskan bahwa jarak zenit (bu'du as-sumti), $\quad h=90^{\circ}-z^{\prime 25} .^{25}$ Atau biasanya diambil dua menit setelah tengah hari. ${ }^{26}$ Dan beberapa hisab praktis, hanya menghitung waktu tengah antara terbit dan tenggelam matahari. waktu pertengahan saat matahari berada di meridian (Meridian Pass) yang dirumuskan dengan $M P-12-c .^{27}$ Waktu inilah yang menjadi patokan hitungan untuk waktu-waktu salat lainnya.

\section{Salat Ashar}

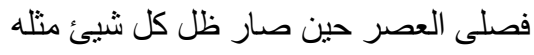

(kemudian Nabi salat Ashar ketika bayag-bayang suatu benda sama dengan aslinya)

$$
\text { فصلى العصر حين صسار ظل كل شئ منله }
$$

(kemudian Nabi salat Ashar ketika bayang-bayang suatu benda dua kali dari aslinya)

(dan waktu Ashar selama matahari belum menguning)

\footnotetext{
${ }^{24}$ Abd. Rachim..., hlm. 23

${ }^{25}$ Abd. Rachim, hlm. 14-15

26 Moedji Raharto Tarmi..., yang dikutip dari Mohammad Ilyas, A Modern Guide to Islamic Calendar, Times \& Qibla,

${ }^{27}$ Muhyiddin Khazin..., hlm. 88
} 1984, hlm. 55
Meskipun secara garis besar dapat dikatakan bahwa awal waktu Ashar adalah sejak bayangan sama dengan tinggi benda sebenarnya, tapi hal ini masih menimbulkan beberapa penafsiran. Dalam hadis riwayat Jabir bin Abdullah r.a Nabi Saw diajak salat Ashar oleh malaikat Jibril ketika panjang bayangan sama dengan tinggi benda sebenarnya dan pada keesokan harinya Nabi diajak pada saat panjang bayangan dua kali tinggi benda sebenarnya. $^{28}$

Menurut Imam Malik akhir waktu Dzuhur adalah waktu musyatarok (waktu untuk dua salat), Imam Syafi'i, Abu Tsaur dan Daud berpendapat akhir waktu Dzuhur adalah masuk waktu Ashar; yaitu ketika panjang bayang-bayang suatu benda melebihi panjang benda sebenarnya. Sedangkan Abu Hanifah berpendapat bahwa awal waktu Ashar ketika bayang-bayang sesuatu sama dengan dua kali bendanya. ${ }^{29}$

Dan dalam penetapan akhir waktu salat Ashar juga ada perbedaan antara hadits Imamatu Jibril dengan hadits Abdillah, yaitu yang pertama dalam hadits Imamatu Jibril sesungguhnya akhir waktu Ashar itu adalah ketika benda itu sama dengan dua kali bayang-bayangnya (pendapat Imam Syafi'i) ${ }^{30}$, dalam hadits Abdillah

hlm. 74

28 Muhammad Jawa Mughniyyah...,

29 Lihat pada Syamsudin Sarakhsi, Kitab Al-Mabsuth Juz 1-2, (Beirut: Darul Kitab Al-Ilmiyah), hlm 143. Dalam kitabini disebutkan bahwa,

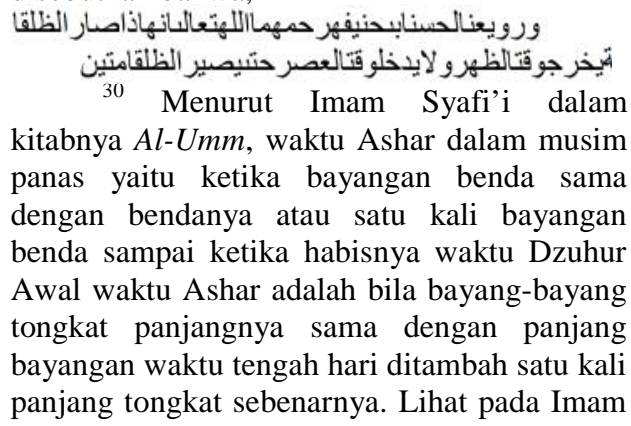


sebelum menguningnya matahari (pendapat Imam Ahmad bin Hambal), dan dalam hadist Abu Hurairah akhir waktu Ashar sebelum terbenamnya matahari kira-kira satu raka'at (pendapat Ahli Dhahir). ${ }^{31}$

Kedua waktu masuknya waktu Ashar ini dimungkinkan karena fenomena seperti itu tidak dapat digeneralisasi akibat bergantung pada musim atau posisi tahunan matahari. Pada musim dingin hal itu bisa dicapai pada waktu Dzuhur, bahkan mungkin tidak pernah terjadi karena bayangan selalu lebih panjang dari pada tongkatnya.

Sementara pendapat yang memperhitungkan panjang bayangan pada waktu Dzuhur atau mengambil dasar tambahannya dua kali panjang tongkat (di beberapa negara Eropa) dianalisir sebagai solusi yang dimaksudkan untuk mengatasi masalah panjang bayangan pada musim dingin. ${ }^{32}$ Untuk masyarakat Indonesia

Abi Abdillah Muhammad Bin Idris AsySyafi'i, Al-Umm, (Beirut: Dar Al-Kitab, Juz I, tt), hlm 153 .

${ }^{31}$ Al Faqih Abul Wahid Muhammad Bin Ahmad Bin Muhammad Ibnu Rusyd,Bidayatul Mujatahid Analisa Fiqih Para Mujtahid, diterjemahkan oleh Imam Ghazali dkk, dari Bidayatul Mujtahid Wa Nihayatul Muqtasid, (Jakarta: Pustaka Amani, 2007), hlm. 205.

${ }^{32}$ Departemen Agama RI..., (Penentuan Jadwal Waktu Salat Sepanjang Masa), hlm 29. Sedangkan Saadoe'ddin Djambek dalam pendapatnya menyatakan bahwa di antara dua pendapat antara Imam Hanafi dan Syafi'i yang dijadikan landasan dalam penentuan awal waktu salat Ashar adalah pendapat Imam Hanafi dengan alasan pendapat Imam Hanafi juga mempertimbangkan daerah-daerah kutub, dimana matahari pada awal Dzuhur tidak begitu tinggi kedudukannya di langit dan dalam keadaan demikian bayang-bayang memanjang lebih cepat dari pada ketika matahari pada tengah hari berkedudukan tinggi di langit seperti di negeri kita. Jika kita menggunakan pendapat Syafi'i sebagai syarat masuknya awal waktu Ashar maka masuknya waktu Asar akan lebih cepat dan akibatnya waktu Dzuhur menjadi terlalu pendek dan sendiri, digunakan pendapat yang pertama, yaitu masuknya waktu Ashar adalah saat bayang-bayang seseorang atau suatu benda sama dengan seseorang atau benda tersebut. Secara astronomis dapat digambarkan sebagai berikut:

$$
\begin{aligned}
& \mathrm{AB}=\text { tongkat tegak lurus } \\
& \text { sepanjang } \boldsymbol{a} \\
& \text { Saat kulminasi, bayang-bayang }
\end{aligned}
$$
ujung tongkat $\mathrm{A}$ jatuh pada titik $\mathrm{C}$. Bayang seluruhnya ialah B-C yang panjangnya $\boldsymbol{b}$.

CAm menuju pada titik pusat matahari sewaktu di meridian. Jadi sudut zAm ialah jarak dari titik zenith ke titik pusat matahari yang dinamakan $z m$. Bila matahari bergerak ke Barat melewati titik kulminasi dan kedudukannya semakin rendah, mis. di titik as, maka bayangan tongkat $\mathrm{AB}$ semakin panjang. Pada awal Ashar, panjang bayangan itu adalah BCD, yaitu $\mathrm{BC}+\mathrm{CD}$. Jadi panjang bayangbayang $\mathrm{AB}$ waktu Ashar $=\mathrm{b}+\mathrm{a}$.

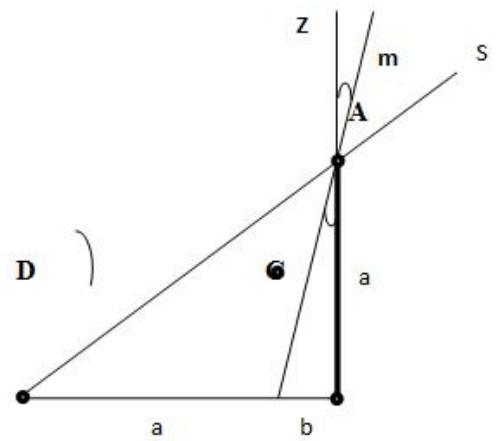

Gambar 1. Bayangan waktu Ashar.

Sudut ABD ialah tinggi matahari pada awal waktu Ashar,

waktu Asar akan terlau panjang. Selengkapnya baca Wahbah az-Zuhaili. Al-Fiqh al-Islamiy wa Adillatuhu, cet. II (Beirut: Dar al-Fikr, 1989), Jilid I : 509. Baca juga Hasbi ashShiddiqie. Pedoman Salat, (Jakarta: Bulan Bintang, 1978), cet. X, hlm. 128. Perhatikan pula Saadoe'ddin Jambek, Salat dan Puasa di daerah Kutub, cet. I, (Jakarta: Bulan Bintang), 1974, hlm 9. 


$$
\begin{gathered}
\operatorname{cotg} \mathrm{ADB}=\mathrm{BD} / \mathrm{AB} \\
\operatorname{cotg} \mathrm{ADB}=\frac{\mathrm{b}+\mathbf{a}}{\mathrm{a}}=\frac{\mathrm{b}}{\mathrm{a}}+\frac{\mathrm{b}}{\mathrm{a}}=\frac{\mathrm{b}}{\mathrm{a}}+1
\end{gathered}
$$

$\frac{\mathrm{b}}{\mathrm{a}}$ ialah tan BAC atau tg zAm, jadi $\tan \mathrm{z}_{\mathrm{m}}$.

sehingga diperoleh rumus:

$$
\operatorname{cotg} h a=\tan z m n+1
$$

Cotangent tinggi Ashar sama besarnya dengan tangens jarak zenith titik pusat matahari sewaktu berkulminasi, ditambah dengan bilangan satu. Adapun akhir waktu Ashar adalah ketika terbenamnya matahari. ${ }^{33}$

\section{Salat Maghrib}

..... فصلى المغرب حين وجبت الثمس....

(Nabi salat Magrib ketika matahari terbenam)

$$
\text { .....مثله ثم جاءه المغرب وقتا واحدا لم يزل عنه }
$$

(kemudian datang lagi kepada-Nya diwaktu Magrib dalam waktu yang sama tidak bergeser dari waktu yang sudah)

$$
\text { ........... ... }
$$

(dan waktu magrib selama syafaq belum terbenam)

Dari kedua hadis, ada kesepakatan bahwa awal waktu Maghrib adalah ketika matahari terbenam. Namun, para ulama berbeda pendapat tentang akhir waktu salat Maghrib. Imam Hanafi, Hambali, dan Syafi'i, berpendapat bahwa waktu Maghrib adalah antara tenggelamnya matahari sampai tenggelamnya mega atau sampai hilangnya cahaya merah di arah barat. ${ }^{34}$

${ }^{33}$ Abdr. Rachim..., hlm. 24-25

34 Al Faqih Abul Wahid Muhammad Bin Ahmad Bin Muhammad Ibnu Rusyd..., hlm. 206
Sedangkan Imam Maliki berpendapat, sesungguhnya waktu Maghrib sempit, ia hanya khusus dari awal tenggelamnya matahari sampai di perkirakan dapat melaksanakan salat Maghrib itu, yang termasuk di dalamnya, cukup untuk bersuci dan adzan dan tidak boleh mengakhirkanya (mengundurnya) dari waktu ini, ini hanya pendapat Maliki saja. ${ }^{35}$

Secara astronomi, terbenamnya matahari yang menjadi tanda masuknya awal waktu Maghrib ialah ketika seluruh piringan matahari berada di bawah ufuk yang biasa dikatakan posisi matahari $-1^{\circ}$. Pada saat tersebut, garis ufuk bersingungan dengan piringan matahari bagian atas. Sedangkan besar jarak titik pusat matahari ke ufuk ialah seperdua garis tengah matahari. Garis tengah matahari rata-rata ialah 32', jadi jarak titik pusat matahari ke ufuk ialah $1 / 2 \times 32=16,{ }^{36}$ Oleh karena itu, dalam penentuan waktu Maghrib diformulasikan dengan menambah jarak titik pusat matahari tersebut; atau yang biasa disebut dengan semidiameter matahari; dengan koreksi reraksi yang menggunakan data refraksi rata-rata pada saat Maghrib senilai $0^{\circ} \quad 34^{\prime}$; serta kerendahan ufuk. Sehingga diperoleh rumus untuk mencari tinggi matahari $\left(h_{\mathrm{o}}\right)$ pada saat Maghrib adalah sebagai berikut:

$$
h_{o}=-(k u+r e f+s d)
$$

35 Muhammad Jawa Mughniyyah..., hlm.75. Untuk akhir waktu Maghrib, ada riwayat mengatakan pada hilangnya mega merah (Asy Syafaq Al Ahmar) menurut Qoul Jadid yang sependapat dengan Abu Ishaq, Ats Tsaury, Abu Tsaur, Ashab Ar Ra'yi dan sebagian Ashab Asy Syafi'i. Dan ada juga riwayat yang mengatakan bahwa waktu Maghrib hanya seukuran Wudhu, adzan, iqamat, salat Maghrib, dzikir dan salat sunnah dua raka'at. Pendapat kedua ini menurut Qaul Qadim Imam Syafi'i.

${ }^{36}$ Abd. Rachim..., hlm. 26 
4. Salat Isya'

$$
\text { فصلى العشاء حين غاب الثفق }
$$

(kemudian Nabi salat Isya' ketika mega merah telah terbenam)

$$
\begin{aligned}
& \text { جاءه العشاء حين ذهب نصف الليل اوقال ثلث الليل } \\
& \text { فقال قم فصله فصلى العشاء العاء الصاء }
\end{aligned}
$$

(kemudian datang lagi kepadanya di waktu Isya dikala telah lewat separuh malam atau ia berkata telah hilang sepertiga malam, kemudian Nabi salat Isya')

$$
\text { ووقت صلاة العشاء الى نصف اليل الاوسط }
$$

(dan waktu Isya' sampai pertengahan malam)

Permulaan waktu Isya' dari keterangan hadis tersebut dapat diketahui bahwa pada saat hilangnya mega merah dan berlangsung hingga tengah malam. Namun, dari kedua hadis tersebut, hadis kedua menyebutkan bahwa batas waktu Isya' hingga tengah malam. Sedangkan pada hadis pertama, disebutkan bahwa Jibril baru datang ; dihari kedua; ketika telah lewat separuh malam atau sepertiga malam, kemudian Nabi salat Isya'. Dari situ, ada tiga pendapat untuk batas waktu Isya', yang pertama sampai sepertiga malam (menurut Syafi'i dan Abu Hanifah), kedua sampai separoh malam (menurut Imam Malik), dan terakhir sampai terbit fajar (menurut imam Daud). ${ }^{37}$

37 Al Faqih Abul Wahid Muhammad Bin Ahmad Bin Muhammad Ibnu Rusyd..., hlm. 210. Pendapat pertama bahwa akhir waktu Isya' adalah pada pertengahan malam dilansir oleh Ats Tsaury, Ashab ar Ra'yi (ulama yang condong pada akal dalam proses ijtihadnya), Ibnu Al Mubarak, Ishaq bin Rawaih dan Abu Hanifah. Sedangkan akhir waktu Isya' ialah sepertiga malam seperti yang dilansir oleh Umar bin Khattab, Abu Hurairah, Umar bin Abdul Aziz dan Asy Syafi'i (pada salah satu riwayat dari Ishaq bin Ibrahim dari Jarir dari Manshur). Untuk akhir waktu Isya “ saat terbitnya fajar sebagaimana dilansir oleh Asy Syafi'i (pada riwayat lain), Abdullah bin Abbas, Atha', Thawus, Ikrimah dan Ahlu Ar
Di Indonesia, para ulama sepakat bahwa waktu Isya' ditandai dengan mulai memudarnya mega merah (asy-Syafaq al-Ahmar) di bagian langit sebelah barat, yaitu tanda masuknya gelap malam. Peristiwa ini dalam falak ilmiy dikenal sebagai akhir senja astronomi (astronomical twilight). ${ }^{38}$

Secara astronomis, apabila matahari telah di bawah ufuk, cahaya yang langsung mengenai bumi telah tidak ada, yang ada hanya cahaya yang dipantulkan dan dibiaskan oleh partikel-partikel halus yang berada di udara hingga mencapai mata pengamat. Kadar penyebaran cahaya oleh partikel-partikel tersebut berbanding sebagai kebalikan pangkat empat panjang gelombang. Gelombang yang terpendek ialah sinar biru, sedangkan yang paling panjang adalah sinar merah. Sinar merah ini yang biasa disebut mega merah. ${ }^{39}$

Rifahiyyah. Selengkapnya lihat pada Sa'id bin Muhammad Ba'asyun, Busyr Al Karim Syarh Al Muqadimah Al Hadhramiyah, (Beirut: Dar Ihya Al Kutub Al Arabiyah, tt), hlm. 56

38 There is one phenomenon that lengthens the fraction of the day given over to daylight. Even after the sun has set, some sunlight is received by the observer, scattered and reflected by the earth's asmosphere. As the sun sinks further below the horizon, the intensity of this light diminishes. The phenomenon is called twilight and is classified as civil, nautical or astronomical twilight. Civil twilight is said to end when the sun's centre is $6^{\circ}$ below horizon, nautical twilight ends when centre $12^{\circ}$ below the horizon, while astronomical twilight ands when the centre of the sun's is $18^{\circ}$ below the horizon. Twilight is a nuisance, astronomically speaking, often preventing the observation of very faint celestial objects. We shall see below that in some latitudes during part of the year, twilight is indeed continuous throughtout the night, evening and morning twilight merging because the sun's centre at all times of the night is less than $18^{\circ}$ below the horizon. Lihat A. E. Roy, D. Clarke, Astronomy Principles and Practise, published by Adam Hilger, (Bristol: Techno House, 1936), hlm. 83.

$$
{ }^{39} \text { Abd Rachim..., hlm. 38-39 }
$$


Waktu Isya' dapat diketahui pada saat peristiwa dusk astronomical twilight, yaitu ketika langit tampak gelap karena cahaya matahari di bawah ufuk tidak dapat lagi dibiaskan oleh atmosfer. Dalam referensi standar astronomi, sudut altitude untuk astronomical twilight adalah $18^{\circ}$ di bawah ufuk, atau sama dengan $-18^{\circ} .{ }^{40}$

Hal ini berarti, bayangan merah setelah terbenamnya matahari tidak terlihat lagi jika matahari berada pada $18^{\circ}$ di bawah ufuk $\left(-18^{\circ}\right)$, dengan jarak pusat matahari sama dengan $108^{\circ}$ (posisi matahari tenggelam $90^{\circ}+18^{\circ}$ ) Ketentuan $\mathrm{h}$ Isya' $-18^{\circ}$ ini dipegang oleh Saadoeddin Djambek dan dalam beberapa keterangan-keterangan pada berbagai kesempatan oleh Abdur Rachim serta Husen kamluddin. ${ }^{41}$

\section{Salat Subuh}

$$
\text { فصلى الفجر حين برق الفجر الفجر او قال سطع }
$$

(lalu Nabi salat Fajar dikala fajar menyingsing atau ia berkata diwaktu fajar bersinar)

$$
\text { جاءه حين اسفر جدا فقال قم فصله فصلى الفجر }
$$

(kemudian ia datang lagi kepada-Nya dikala telah bercahaya benar dan ia berkata: bangunlah dan salatlah kemudian Nabi salat Fajar)

(dan waktu Subuh mulai fajar menyingsiang sampai matahari belum terbit)

Kedua hadis telah jelas menyebutkan bahwa waktu Subuh adalah waktu mulai terbitnya fajar

${ }^{40}$ Rinto Anugraha, dalam artikel yang ditulis, Cara Menghitung Waktu Salat, yang diakses di www.eramuslim.com pada tanggal 13 November 2010

41 Saadoe'ddin Djambek, Pedoman Waktu Salat Sepanjang Masa,(Jakarta: Bulan Bintang, 1394), hlm. 32 shadiq dan berlangsung hingga terbitnya matahari. Para ahli fiqh sepakat dengan pendapat tersebut, meskipun ada beberapa ahli fiqh Syafi'iyah yang menyimpulkan bahwa batas akhir waktu Subuh adalah sampai tampaknya sinar matahari. ${ }^{42}$

Fajar shadiq ${ }^{43}$ dapat dipahami sebagai dawnastronomical twilight (fajar astronomi), yaitu ketika langit tidak lagi gelap dimana atmosfer bumi mampu membiaskan cahaya matahari dari bawah ufuk. Cahaya ini mulai muncul di ufuk timur menjelang terbit matahari pada saat matahari berada sekitar $18^{\circ}$ di bawah ufuk (atau jarak zenit matahari $=108^{\circ}$ derajat). Pendapat lain menyatakan bahwa terbitnya fajar sidik dimulai pada saat posisi matahari $20^{\circ}$ derajat di bawah ufuk atau jarak zenit matahari adalah $110^{\circ}\left(90^{\circ}+\right.$ $\left.20^{\circ}\right)^{44}$

Di Indonesia pada umumnya, Subuh dimulai pada saat kedudukan matahari $20^{\circ}$ derajat di bawah ufuk hakiki (true horizon). Hal ini bisa dilihat misalnya pendapat ahli falak terkemuka Indonesia, yaitu Saadoe'ddin Djambek disebut-sebut oleh banyak kalangan sebagai mujaddid al-hisab (pembaharu pemikiran hisab) di Indonesia. Beliau menyatakan bahwa waktu Subuh dimulai dengan tampaknya fajar di bawah ufuk sebelah timur dan berakhir dengan terbitnya matahari. Menurutnya dalam ilmu falak saat tampaknya fajar didefinisikan dengan posisi matahari sebesar $20^{\circ}$ dibawah ufuk sebelah timur. ${ }^{45}$ Sementara itu

${ }^{42}$ Al Faqih Abul Wahid Muhammad Bin Ahmad Bin Muhammad Ibnu Rusyd..., hlm. 213

43 Fajar shidiq disebabkan oleh hamburan cahaya matahari di atmosfer atas. Berbeda dengan fajar kidzib (cahaya zodiak), yang disebabkan oleh hamburan cahaya matahari oleh debu-debu antarplanet.

${ }^{44}$ Abd Rachim..., hlm.39

45 Saadoe'ddin Djambek..., hlm. 45. Untuk h matahari saat terbitnya fajar shadiq 
batas akhir waktu Subuh adalah waktu Syuruq (terbit), yaitu $-1^{\circ}$.

\section{Penutup}

Pada mulanya waktu salat hanya bisa ditentukan dengan fenomena alam sebab dalam ayat- alQur'an dan hadis, waktu salat bisa diketahui melalui pergerakan matahari. Hal ini kemudian dikembangkan oleh ulama fikih menjadi sebuah formula menentukan waktu salat. Selanjutnya, perkembangan Islam mempengaruhi cara pandang para ilmuwan untuk membuat rumusan detail mengenai waktu salat dengan melibatkan ilmu astronomi yang matematis. Usaha para ulama tersebut kemudian membuahkan sebuah disiplin ilmu yang khusus membahas tentang perhitungan awal waktu salat. Namun demikian, perhitungan tersebut tetap didasarkan pada pola yang sudah ditetapkan oleh para ahli fikih. Kesimpulan yang dapat diambil dari pembahasan di atas, bahwa telah terjadi simbiosis mutualisme antara ilmu fikih dan sains sehingga memberikan kemudahan umat Islam dalam menentukan awal waktu salat.[]

\section{Daftar Pustaka}

dan fajarkidzib sendiri terdapat perbedaan dari beberapa kalangan ahli falak dan ahli astronomi. Abu Raihan Al Biruni berpendapat h matahari untuk waktu Subuh adalah sekitar $15^{\circ}$ hingga $-18^{\circ}$. Dalam Al-khulashatul Wafiyah fil falaki Jadawidil Lughritimiyah (Zubair umar al-jaelani) hlm. 176, dan Ilmu Falak (Kosmografi) (P. Sima-Mora) hlm.82 disebutkan bahwa $h$ matahari saat Subuh adalah $-18^{\circ}$. Sedangkan dalam Taqribul Maqshad fil 'amali bir rubu'il Mujayyab (Muhammad Muhtar bin Atharid al-Jawi alBogori) hlm. 20, ad-Durusul Falakiyah (Muhammad Ma'shumm bin Ali alMaskumambangi) hlm.12, dan Ilmu Hisab dan Falak (KRT Muhammad Wardan Diponingrat) hlm. 72, menyebutkan bahwa h matahari saat Subuh adalah $-19^{\circ}$ sebagaimana Ibnu Yunus, Al Khalily, Ibnu Syathhir dan Ath Thusiy.
Abi al-Fadhal Ahmad bin Ali bin Hajar Al Asqalani, Syekh Syihabuddin, Tahdzib al Tahdzib, Beirut: Dar Al Kitab Al Islami, $852 \mathrm{H}$

Abi Muhammad Abd Rahman bin Abi Hatim Muhammad, Syekh Islam, Al Jarah wa Ta'dil, Beirut: Dar Al Kutub, 1373 H

A. E. Roy, D. Clarke, Astronomy: Principles and Practice, Bristol: Techno House, 1978

Azhari, Susiknan, Ensiklopedi Hisab Rukyat, Yogyakarta: Pustaka Pelajar, cet. 1, 2005

Badan Hisab Rukyat Departemen Agama, Pedoman Penentuan Jadwal Awal Waktu Shalat Sepanjang Masa, Jakarta, 1994

Djambek, Sa'aduddin, Pedoman Waktu Shalat Sepanjang Masa, Jakarta: Bulan Bintang, 1394

Salat dan Puasa di daerah Kutub, cet. I, Jakarta : Bulan Bintang, 1974

Hasbi ash-Shiddieqy, Teungku Muhammad, Pedoman Salat, cet. X , Jakarta : Bulan Bintang, 1978

Ibnu Rusyd, Al Faqih Abul Wahid Muhammad Bin Ahmad Bin Muhammad, Bidayatul Mujatahid Analisa Fiqih Para Mujtahid, di terjemahkan oleh Imam Ghazali dkk, dari Bidayatul Mujtahid Wa Nihayatul Muqtasid, Jakarta : Pustaka Amani, 2007

Imam Abi Abdillah Muhammad Bin Idris Asy-Syafi'i, Al-Umm, Beirut-Libanon : Dar AlKitab, Juz I, tt

Jawa Mughniyyah, Muhammad, Fiqih Lima Madzhab, Diterjemahkan oleh Masykur dkk dari Al-Fiqh 'ala AlMadzahib Al-Khamsah, Jakarta : Lentera, cet VI, 2007 
Jawad Muqniyyah, Muhammad, AtTafsir al-Kasif, 15:74,

K.J. Vilianueva, Pengantar ke dalam Astronomi Geodesi, Bandung: Departemen Geodesi Fakultas Teknik Sipil dan Perencanaan Institut Teknologi Bandung, 1978

Khazin, Muhyiddin, Ilmu Falak; dalam Teori dan Praktik, Yogyakarta: Buana Pustaka, tt Kamus Ilmu Falak, Yogyakarta: Buana Pustaka, 2005.
KRM. Wardan, Kitab Ilmu Falak dan Hisab, Yogyakarta: cet I, 1957

Muntoha, Analisis Terhadap Toleransi Pengaruh Perbedaan Lintang dan Bujur dalam Kesamaan Penentuan Awal Waktu Shalat, Skripsi Fakultas Syariah IAIN Walisongo Semarang, 2004

Rachim, Abd, Ilmu Falak, Yogyakarta: Liberti, 1983

Umar Al Jailani, Zubair, Khulashatul Al Wafiyah, (Kudus: Penerbit Menara Kudus, tt. 